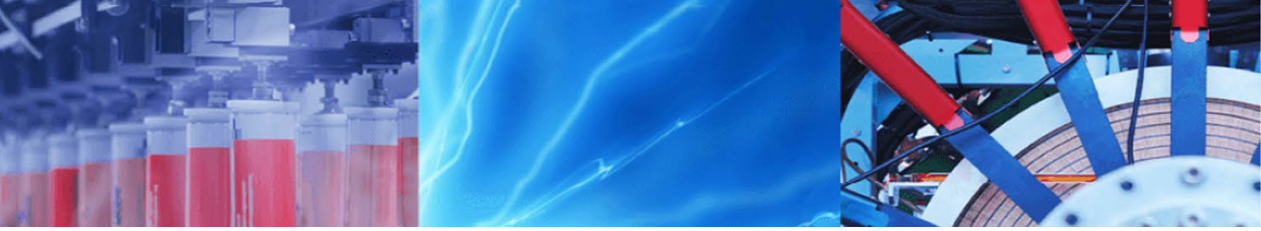

Research Article

\title{
Investigation of removal of anthocyanin in turnip juice wastewater by using different adsorbents
}

\author{
Şevket Tulun ${ }^{1} \cdot$ İsmail Şimşek ${ }^{1} \cdot$ Tolga Bahadır $^{1} \cdot$ Hakan Çelebi $^{1}[$
}

(c) Springer Nature Switzerland AG 2019

\begin{abstract}
The aim of this study is to eliminate the colour pigment of anthocyanin in the composition of turnip juice under different experimental conditions using low cost adsorbents (eggshells, pumpkin seed hulls, almond shells, black-green-red tea wastes, natural clay material). For this purpose, a series of discrete adsorption experiments were performed. Contact time for each set of experiments, adsorbent amount, mixing speed and temperature were fixed at $30 \mathrm{~min}, 2 \mathrm{~g}, 150 \mathrm{rpm}$ and $20^{\circ} \mathrm{C}$. The effects of $\mathrm{pH}$ change of wastewater (acidic-neutral-basic) on colour removal and adsorption process were examined. The most important advantage of using such adsorbents is their ability to solve colour pollution problem as effective and economical adsorption. As a result of the studies, the colour parameter of the anthocyanins was removed from the wastewater at a low rate (14.08\%).
\end{abstract}

Keywords Adsorption · Adsorbent · Anthocyanin · Colour · Turnip juice · Wastewater

\section{Introduction}

Since the fermentation increases the taste, aroma, composition, nutritive value and shelf life of nutrients, it is possible to find fermented products (cheese, yoghurt, pickles, kefir, boza, tarhana and turnip juice) in every society [1-3]. Turnip juice is one of the fermented products to be produced locally and is defined as an extract, purple carrot (Daucus carota), turnip (Brassica rapa) and if desired, a product that is obtained by mixing turnip juice, bulgur flour, sour paste $[4,5]$. Turnip juice produced by lactic acid fermentation is a red-coloured, sour-tasting and fuzzy beverage and the basic raw material used in the production is stated as purple carrots. The turnip juice is produced in Adana, Mersin, Gaziantep, Hatay, Kahramanmaraş and Osmaniye provinces in Turkey [6]. The unique colour of the turnip juice comes from the anthocyanins in the composition of purple carrot, which is the main material. It is stated that the anthocyanin content of turnips juice is between 94 and $238 \mathrm{mg} / \mathrm{L}$ [7]. Turnip juice is of great importance for health. Therefore, there appears to be an emerging industry in Turkey $[6,8]$.

There is no standard flow chart in the production of turnip juice, mainly due to its traditional production. Two different methods are applied to the production of turnip juice. Traditional turnip juice production takes place in two stages (Fig. 1). The first phase is the phase where the dough fermentation takes place, and lactic acid bacteria are enriched at this stage. In the second phase, carrot fermentation takes place and during fermentation, anthocyanins pass into the fluid. $15-20 \%$ solids content of turnip juice consists of approximate size $2 \mathrm{~cm}$ turnip pieces $[9,10]$. With this method, the fermentation is carried out at single stage and at room temperature by adding $20 \%$ purple carrot, $3 \%$ bulgur flour, $1 \%$ salt, $0.2 \%$ bread yeast and water to the fermentation tank in the production of turnip juice (Fig. 2) [11-13]. Purple carrot is a rich source of anthocyanin, the main ingredient used in the production of turnip juice. Purple carrots are mostly grown in Turkey, Afghanistan, Egypt, Pakistan and India. Ereğli district in Konya is the main production region of purple carrot in

Hakan Çelebi, hakanaz.celebi@gmail.com | 'Department of Environmental Engineering, Aksaray University, 68100 Aksaray, Turkey.

SN Applied Sciences (2019) 1:967| https://doi.org/10.1007/s42452-019-1019-x 


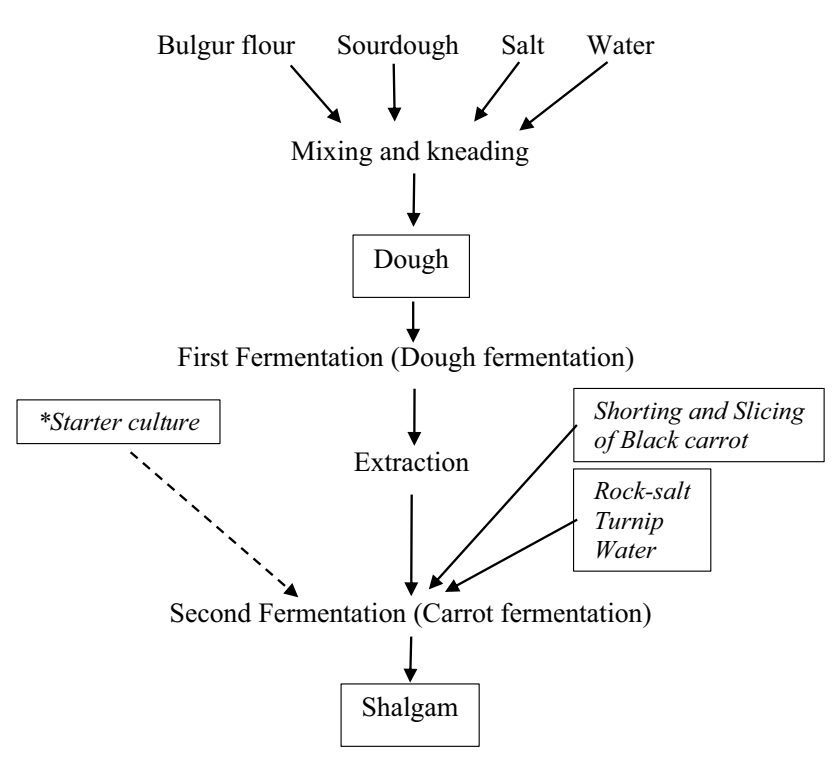

Fig. 1 Turnip juice production by traditional method [11]

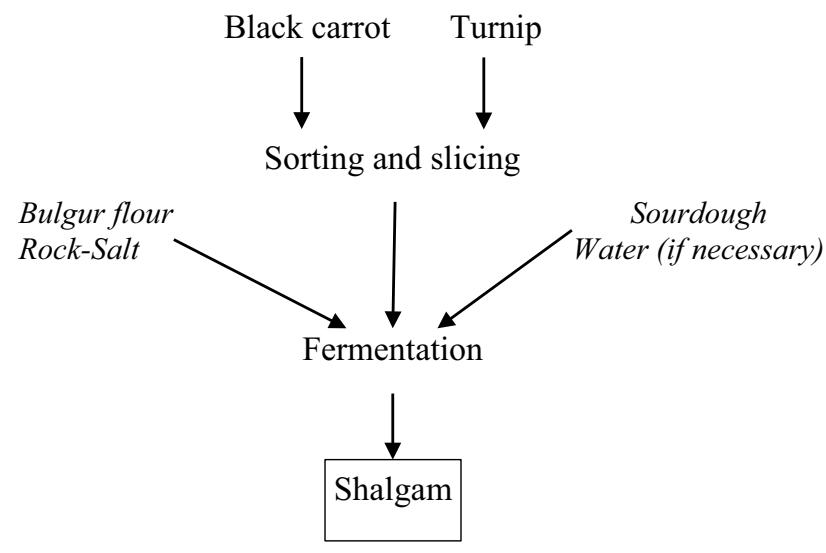

Fig. 2 Turnip juice production by direct method [11]

Turkey $[10,14,15]$. Purple carrots contain a high amount of anthocyanin that is found to be fresh in $1750 \mathrm{mg} / \mathrm{kg}$ $[16,17]$.

The main anthocyanins to be found in purple carrots are cyanide-based, cyanide-3-xylosyl-lukoil-galactoside, cyanide-3-xylosyl-galactose, cyanide 3-xylosyl-glycosinolate derivatives as synoptic ferulic and coumaric acid derivatives of the form (Fig. 3) [18-21]. Anthocyanins have become increasingly important today because of their natural colouring material for the food industry $[22,23]$. According to the numbering system used by the Codex Alimentarius Commission, anthocyanins are listed as natural colouring by European Union legislation and are encoded as E163 [18, 24, 25].

Industrial wastewater differs greatly from domestic wastewater in character, source and quantity. Industrial waste must be controlled by factors that cause pollution of the environment and treated to prevent the use of used water of industrial facilities from contaminating the natural water environment. In particular, colour waste is usually caused by industrial activities, and the textile, leather, food, paper industries are the most common industries to be found. These coloured wastes can cause problems both in the provision of discharge parameters and in the environmental absorption. In addition, it is a known fact that it will cause physical view and odour pollution. In the production of turnip water, coloured wastewater is formed for the washing of carrots and tanks. A series of processes have been developed and studied for the treatment of such wastes that give colour to the receptor environment. Some of them are coagulation and aggregation, ozone, membrane-type filtration, photocatalytic oxidation, electrochemical and biological treatment [26]. However, many of these methods limit the high operating costs and excessive use of sludge production. Adsorption is a method applied successfully and effectively to remove the dyes from the waste $[27,28]$. Low cost, high efficiency, easy applicability, the ability to minimize biological or chemical wastes, lack of extra substances, adsorb and the possibility of adsorbing recovery are some of the key advantages of adsorption $[29,30]$. There are many agricultural and forest-based products that can be used as adsorbent [31, 32]. In this study, the chemical profile of the turnip water produced by fermentation was evaluated in accordance with the literature and the removal of the anthocyanin colour pigment in the structure of turnip water and in the wastewater content after production was investigated using different adsorbents. This research was carried out in wastewater laboratories of Aksaray University Environmental Engineering Department between January and February of 2019 for 2 months. The most important difference of this study compared with others is that when examined in previous years, no studies have been found using the adsorption process of the colour parameter of turnip juice production waste. Moreover, compared with others, the most important difference of this study is to use the batch experimental operation without changing the adsorbents. There are some studies in the literature to remove different synthetic dyes with modified adsorbents. However, there are not many studies on natural dyes. In this study, experiments were performed with natural adsorbents instead of modified adsorbents. In order to extract anthocyanin from wastewater, the study used evaluable waste eggshells, pumpkin seed shells, almond shells, black-green-red tea wastes, natural clay material as potential adsorbents. These adsorbents have been selected as waste and garbage due to their high amount of forms coming from homes, workplaces and 


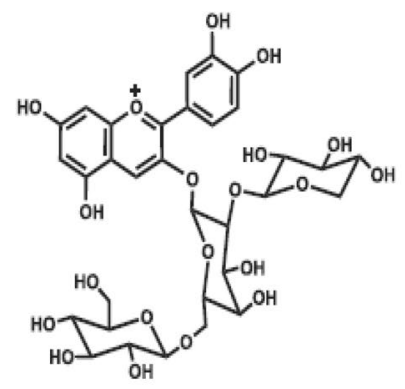

(1)

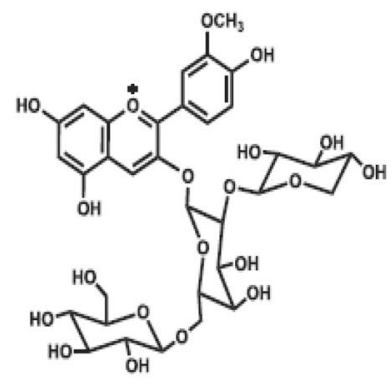

(4)

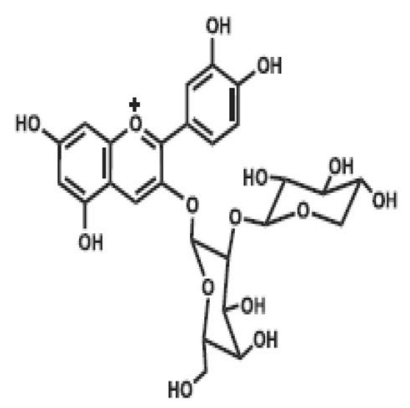

(2)

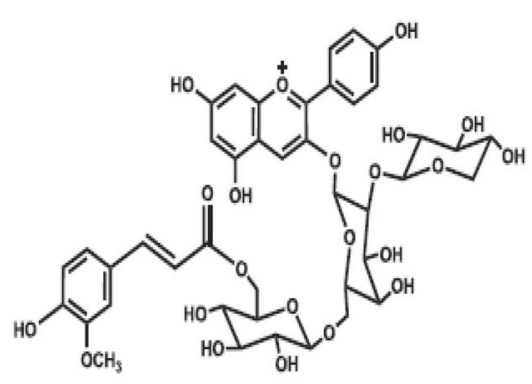

(5)

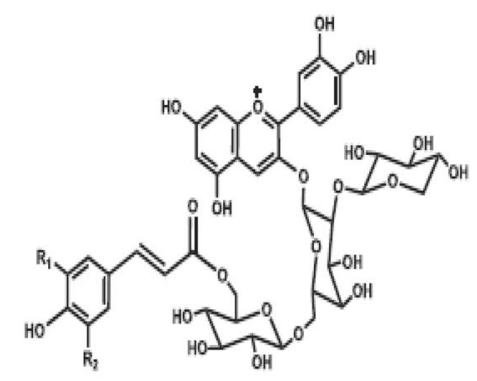

(3)

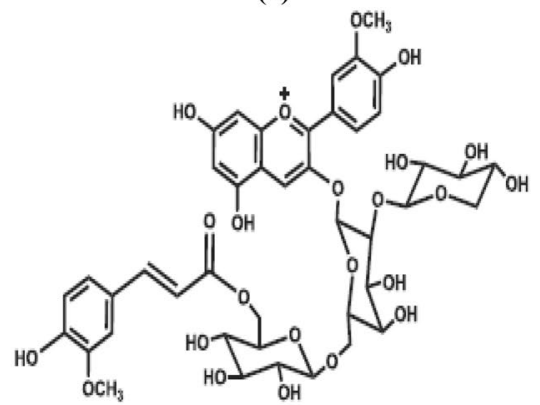

(6)
Fig. 3 Anthocyanin groups in the purple carrots [18, 21]: (1) cyanidin 3-xylosyl-glucosyl-galactoside, (2) cyanidin 3-xylosyl-galactoside, (3) sinapic acid derivative of cyanidin 3-xylosylglucosylgalac-

industries. The application of these selected materials has two advantages: First, they can perform as an effective and economical adsorbent to dissolve colour contamination. Another advantage is that these wastes, which are accepted as garbage all over the world, can be used in a powerful and beneficial way. Thus, sustainability in terms of both environmental and wastewater treatment is handled in an adequate and cost-effective manner.

\section{Methodology}

\subsection{Wastewater characterisation}

The wastewater sample used in the study was taken from the washing water used for tank cleaning of a plant producing turnip water in Ereğli district of Konya. Characterization analysis of wastewater was carried out in the Environmental Engineering Department of Aksaray University. For the experiments, the samples were brought to the laboratory within $24 \mathrm{~h}$ by cold chain and analysed at room temperature. In the study of wastewater samples, the methods accepted and proposed in the whole world and applied frequently in Turkey were used [33]. As a result of the experiments carried out, the results of toside, (4) peonidin 3-xylosyl-glucosyl-galactoside, (5) ferulic acid derivative of pelargonidin 3-xylosyl-glucosyl-galactoside, (6) ferulic acid derivative of peonidin 3-xylosyl-glucosyl-galactoside

Table 1 Some features of turnip juice wastewater

\begin{tabular}{lll}
\hline Parametre & Unit & Concentration \\
\hline $\mathrm{pH}$ & - & 5.72 \\
Conductivity & $\mu \mathrm{S} / \mathrm{cm}$ & 1523.00 \\
Turbidity & $\mathrm{NTU}$ & 7.00 \\
Suspended solids & $\mathrm{mg} / \mathrm{L}$ & 80.00 \\
Biological oxygen demand $\left(\mathrm{BOD}_{5}\right)$ & $\mathrm{mg} / \mathrm{L}$ & 535.00 \\
Chemical oxygen demand $(\mathrm{COD})$ & $\mathrm{mg} / \mathrm{L}$ & 764.70 \\
\hline
\end{tabular}

the analysis of raw wastewater samples are given in the Table 1.

\subsection{Chemical compounds and microbiological properties of the turnip juice}

The chemical and physical properties of turnip water should be as in Table 2 in accordance with TS 11149 turnip water standard [34]. The $\mathrm{pH}$ value of turnip water in accordance with the standard of turnip water 3.3-3.8, titration acidity in lactic acid $4.5-5.5 \mathrm{~g} / \mathrm{L}$, soluble dry matter at least $2.5 \%$ and salt ratio $2 \%$ at most. The amount of watersoluble in water consists of carbohydrates, salt, organic acids and minerals. In turn, there are trace amounts of saccharose, glucose and fructose sugars. 
Table 2 The values of turnip juice specified in TS 11149 standard [34]

\begin{tabular}{lll}
\hline Parameter & Unit & Concentration \\
\hline Total acidity (in terms of lactic acid) & $\mathrm{g} / \mathrm{L}$ & $\geq 6.0$ \\
$\mathrm{pH}$ & - & $3.3-3.8$ \\
Lactic acid & $\mathrm{g} / \mathrm{L}$ & $4.5-5.5$ \\
Volatile acid (as acetic acid) & $\mathrm{g} / \mathrm{L}$ & $0.7-1.2$ \\
Dry substance & $\%$ & 2.5 \\
Ash $(\mathrm{w} / \mathrm{v})$ & $\%$ & 2.0 \\
Salt $(\mathrm{NaCl}, \mathrm{w} / \mathrm{v})$ & $\%$ & 2.0 \\
Colour & $\mathrm{pH}=1.0$ & Red-purple \\
& $\mathrm{pH}=7.0$ & Gray-green \\
\hline
\end{tabular}

The microbiology of the turnip water is complicated and it is not known in details. The presence of the microorganisms having probiotic proerties such as $L$. plantarum, $L$. helvaticus, L. reuteri, L. fermentum, L. buchneri, L. helvaticus, L. reuteri, Saccharomyces cerevisiae, Lactococcus, Pediococcus, Leuconostoc and L. delbrueckii were found in the studies to be conducted [35-38].

\subsection{Adsorbent preparations}

Almond shell, egg shell, banana shell, pumpkin seed shell, Rooibos (red)-green-black tea waste, clay were used as the absorbents. The wastes used in the research were collected from local markets and houses. Prior to using these materials as adsorbs, the waste washing process was performed several times with pure water for $24 \mathrm{~h}$ at room temperature to remove any dirt particles that might be present on the surface. After washing, all adsorbents have dried in the air oven at $100{ }^{\circ} \mathrm{C}$ for $24 \mathrm{~h}$ (Memmert GmbH Co. $\mathrm{KG}$, Germany). Later, washed and dried adsorbents were crushed using the Retsch GM 200 brand laboratory mill. Prior to adsorption experiments, no chemical or physical process was applied. In this study, almond shell, eggshell, banana shell, pumpkin seed shell, Rooibos (red)-greenblack tea waste, clay minerals used were milled and used in powder form.

\subsection{Devices and chemicals}

All chemicals are analytical (more than $97 \%$ purity) and have been purchased from Merck GmbH (Darmstadt, Germany). The $\mathrm{pH}$ of each solution is set to the desired value using a $\mathrm{pH}$ meter with the addition of $0.01 \mathrm{M} \mathrm{NaOH}$ or $0.01 \mathrm{M}$ $\mathrm{HC} 1$ drops if necessary. For batch adsorption experiments, ZHWY-200B, ZHICHENG analytical model thermal agitator (150 rpm shake rate) was used. Turnip juice wastewater, after sedimentation $0.45 \mu \mathrm{m}$ pore-sized membrane filters is filtered. Colour analysis was performed using the Perkin
Elmer Optima 2100DV model UV/Vis spectrometer. The $\mathrm{pH}$ and conductivity measurements were made with a combination electrode with LABQUEST2 digital ion analyser. The $\mathrm{COD}, \mathrm{BOD}_{5}, \mathrm{TDS}$ analyses were performed as indicated in the standard methods [33].

\subsection{Characterization of adsorbents}

The detailed composition of almond shell, eggshell, banana peel, pumpkin seed hull, Rooibos (red)-green-black tea waste, clay minerals are shown in Table 3 [39-51]. The surface physical morphology of the adsorbents identified by scanning electron microscope (SEM) was evaluated according to previous studies due to lack of laboratory facilities. Scanning electron microscope observations of adsorbents can be seen in Fig. 4 [39-51]. It can be seen that all adsorbents were agglomerated and have an irregular round shape. Also, all adsorbents have many large and medium pores. Through these pores, it is easy to catch and adsorb the dye.

\subsection{Test of adsorbents}

Adsorption studies were carried out at $20^{\circ} \mathrm{C}$ temperature with the help of mechanical agitation in $100 \mathrm{ml}$ conical flasks by adjusting the contact time for each set, adsorb amount, mixing speed and temperature to remain constant. In order to examine the effect of $\mathrm{pH}$ on anthocyanin, the $\mathrm{pH}$ tests were carried out using data in optimum conditions by taking $50 \mathrm{ml}$ of all adsorbents and solutions set in specific $\mathrm{pH}$ values. Due to the negative effect of the temperature on the anthocyanin, all the experiments were conducted at room temperature. When determining the colour parameter, the European norm is based on the standards set according to DIN ISO 7887, the colour measurements were measured at 436-620 nm with visible light Novespec II Spectrophotometer measurements. The aim of using 3 different wavelengths in colour measurement with visual colour number (RES) method is to produce yellow and shades in $400-500 \mathrm{~nm}$ band, red and shades in 500-600 Nm band, Blue and shades in $600-700 \mathrm{~nm}$ band. These measured values are calculated by replacing them in an Eq. 1 below. A, the absorbance value of the sample in $\lambda$ wavelength; $d$, bathtub thickness $(\mathrm{mm})$; $f$, spectral absorption value $(f=1000)$; res $(\lambda)$, $\lambda$ wavelength number of colour (res) value $(1 / \mathrm{m})$

$\operatorname{RES}(\lambda)=\frac{\mathrm{A}}{\mathrm{d}} \times f$

\subsection{Anthocyanins}

The chemical structure of the anthocyanins investigated in the study and the other groups found in the common form in nature is shown in Fig. 5 [52-57]. Anthocyanins 


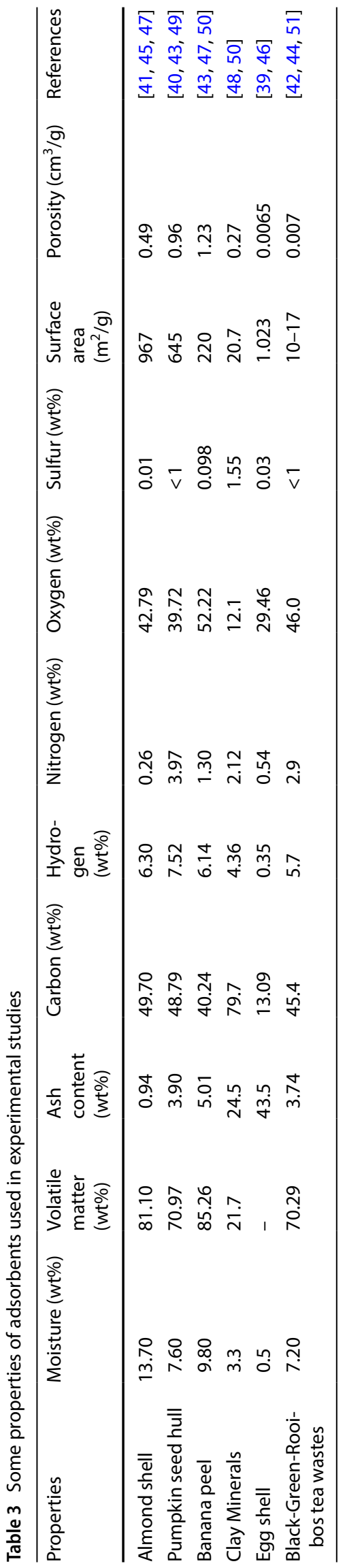

consist of an aromatic ring a connected to a third ring $B$ by a carbon-carbon bond and an oxygen-containing heterocyclic ring $\mathrm{C}$ connected to an aromatic ring $\mathrm{A}$. In the previous studies, as the amount of carrots added to turnip juice increased, the total acidity, dry matter, ash, total phenol, total anthocyanin, colour density and index increased. The distribution of these six anthocyanins commonly found in nature in edible parts of plants is as follows; cyanide (50\%), pelargonidine $(12 \%)$, peonidine $(12 \%)$, delfinidine $(12 \%)$, petunidine (7\%) and malvidine (7\%) [58].

\section{Results and discussion}

\subsection{Effect of $\mathrm{pH}$}

The $\mathrm{pH}$ in the media is one of the most important parameters that affect both the adsorbent surface and the adsorb type. In the study, other parameters were kept constant to investigate the effect of changing $\mathrm{pH}$ values on anthocyanin. The adsorption studies were performed at varying $\mathrm{pH}$ values which were 2.03-3.04-5.72-6.37-7.02-8.92-9.3710.03-11.20. At $20^{\circ} \mathrm{C}$ temperature, $2 \mathrm{~g}$ adsorb was added and the values and colour distributions of the anthocyanin $\mathrm{pH}$ changes in the structure of turnip juice waste water at the end of adsorption lasting 30 min were given in Table 4.

Table 4 shows that an important feature of anthocyanins is the change in colour intensity and tone depending on $\mathrm{pH}$ and even the disappearance of colour. This is due to the chemical complex composition of the molecule of anthocyanin in aqueous environments and its self-rearrangement. In this case, depending on the $\mathrm{pH}$ value, different colours or colourless forms emerge. An anthocyanin produces stable colour only at acidic $\mathrm{pH}$ values. In acidic aqueous solutions, anthocyanins occur in 4 balance types: quinonoid base, flavilium cation, carbinol or pseudomonas base and shield. The main anthocyanin in purple carrots is a phenol glycosylated cyanide, and there is a change in the blue colour above $\mathrm{pH}$ 5.0. In accordance with the analysis and literature, the compounds of anthocyanins act as an indicator based on the $\mathrm{pH}$ value of the medium and give different colours in different $\mathrm{pH}$ values. Anthocyanins often give red colour at low $\mathrm{pH}$ and blue-purple colours at alkaline $\mathrm{pH}$. In light of experimental studies, holding on adsorbent surface is expected to occur according to the $\mathrm{pH}$ value of wastewater and adsorb surface condition. In general, adsorption rate increases in $\mathrm{pH}$ values where substances are neutral. However, since the wastewater structure contains a lot of hydrogen and hydroxide ions chemically, this situation can be associated with the risk of less coating of adsorb, as adhesion competition between these molecules and adsorb may occur. 

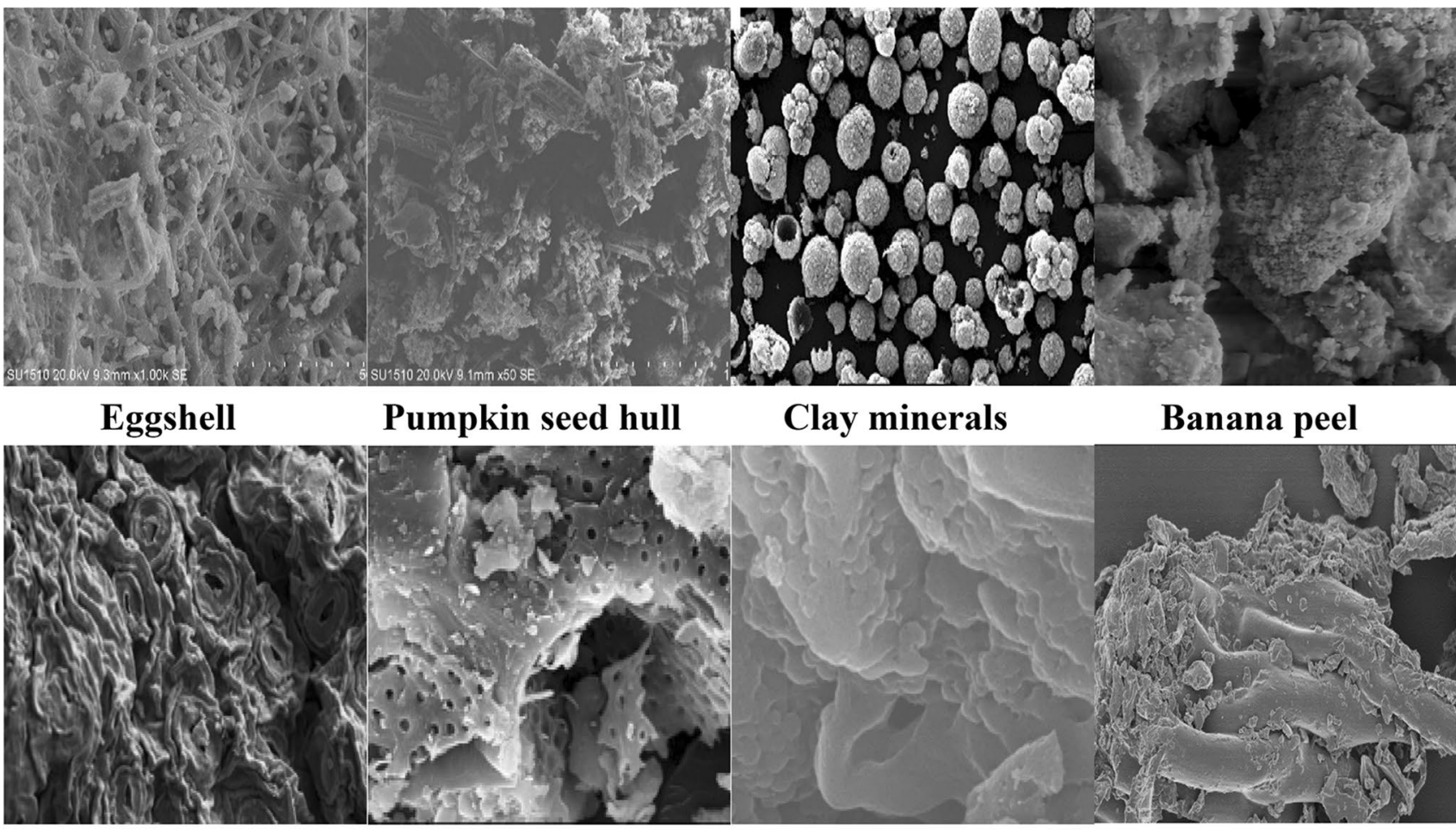

Green tea waste
Clay minerals
Banana peel

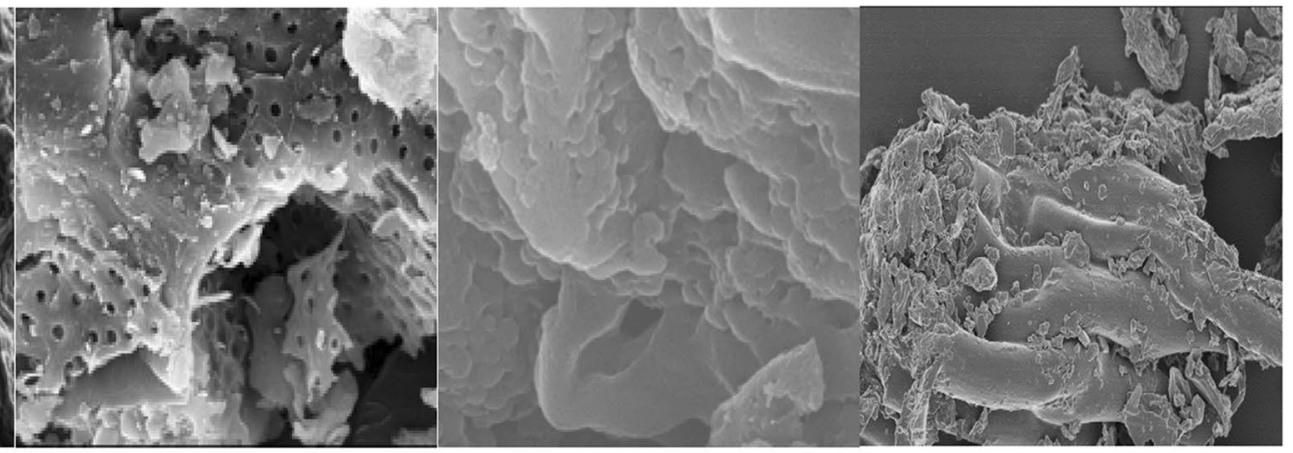

Almond shell

Black tea waste

Roiboss Tea waste

Fig. 4 SEM images of the natural adsorbents

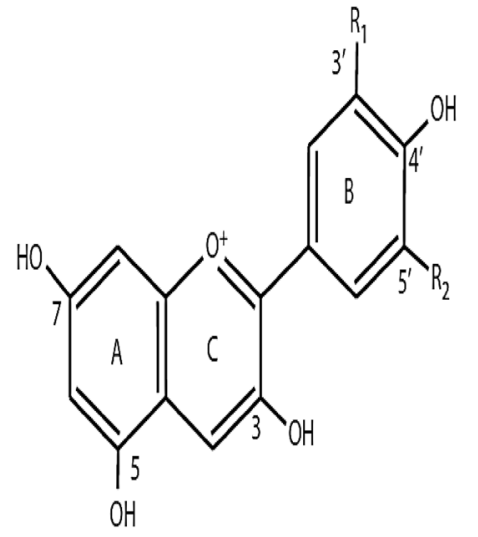

Fig. 5 Structures of anthocyanins commonly found in nature [59, 60]

\subsection{Colour measurements}

In experimental studies, colour removal caused by anthocyanin was not provided with adsorbent materials and anthocyanin played an important role in wastewater such as methyl-orange, phenolphthalein (Fig. 6). In the structure of the used adsorbents, especially iron, aluminium, calcium, copper, magnesium etc. it can be said that many ion groups and molecules of anthocyanins can form complex
Table 4 Anthocyanins colour change status at different $\mathrm{pH}$ values

\begin{tabular}{lll}
\hline $\mathrm{pH}$ value & $\mathrm{pH}$ balancer & Colour change \\
\hline 2.03 & $0.01 \mathrm{M} \mathrm{HC1}$ & Pink-red \\
3.04 & $0.01 \mathrm{M} \mathrm{HC1}$ & Pink-red \\
$5.72^{*}$ & Raw Wastewater & Light purple \\
6.37 & $0.01 \mathrm{M} \mathrm{NaOH}$ & Purple-pink \\
7.02 & $0.01 \mathrm{M} \mathrm{NaOH}$ & Light blue \\
8.92 & $0.01 \mathrm{M} \mathrm{NaOH}$ & Blue \\
9.37 & $0.01 \mathrm{M} \mathrm{NaOH}$ & Blue-green \\
10.03 & $0.01 \mathrm{M} \mathrm{NaOH}$ & Blue-green \\
11.20 & $0.01 \mathrm{M} \mathrm{NaOH}$ & Green \\
\hline
\end{tabular}

*Initial pH value

and eventually become a stable blue or violet of red colour and gain a new chemical structure. As mentioned earlier, there is no specific study in the literature on the treatment and color removal of turnip juice wastewater.

In the basic structure of the anthocyanins consisting of 15 carbon $A$ and $B$, two phenyl rings are connected to each other with a three-carbon structure (Fig. 5). This structure usually forms a second ring and is called the $C$ Ring. In particular, the colour of the anthocyanins is related to the change in the B-ring in chemical structure, and the increase in $\mathrm{OH}$ group number of the B-ring 
Fig. 6 Anthocyanin colour experiment results with different adsorbents

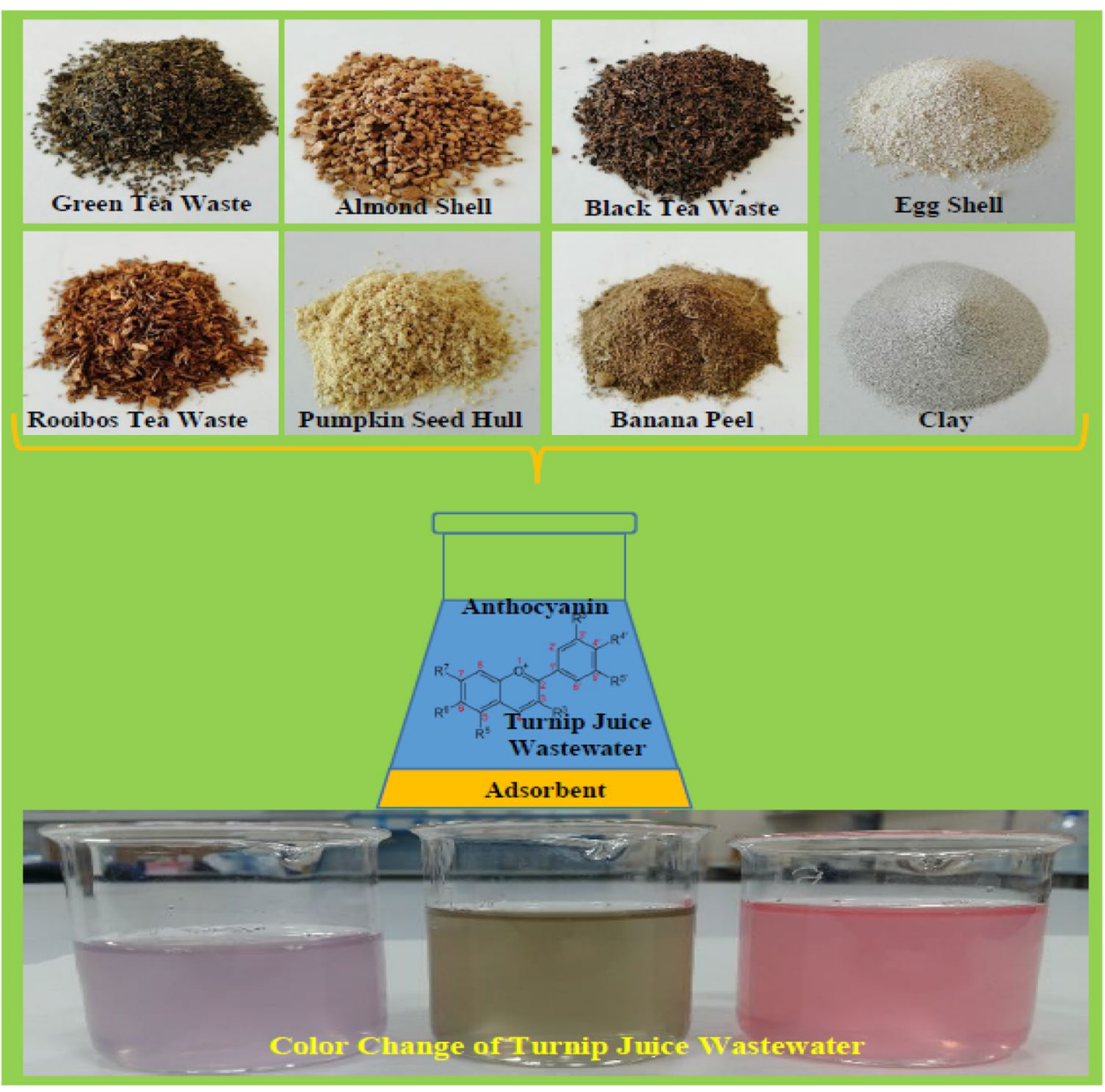

causes the colour of the anthocyanins to become blue and the increase in the $\mathrm{OCH} 3$ group (methoxylation) causes the colour to become red. As the number of $\mathrm{OH}$ groups in the molecule increases, the wavelength of the anthocyanin gives maximum absorption is growing and at this point, the colour becomes a blue form. The increase in the number of $\mathrm{OCH} 3$ groups makes the colour more red as the group of $\mathrm{OH}$ - increases in the chemical form of anthocyanins found in the structure of the wastewater. Because anthocyanins are highly sensitive to $\mathrm{pH}$ because of the groups involved in their chemical structure, they are involved in both the literature and the studies of $\mathrm{pH}$ because it is effective on the colour, intensity, stability and structure of anthocyanins. Colour analysis of the anthocyanins in the present wastewater was performed with RES method and the results were shown in Table 5 and Fig. 6. RES values were calculated by taking the average of 3 repeated studies in the wavelengths of $436-620 \mathrm{~nm}$ range. As a result of $\mathrm{pH}$ and colour tests, the colour removal caused by anthocyanin could not be obtained
Table 5 Calculated RES values of raw wastewater and adsorbents

\begin{tabular}{lll}
\hline RES value $(1 / \mathrm{m})$ & Average values & $\begin{array}{l}\text { Removal } \\
\text { efficiencies } \\
(\%)\end{array}$ \\
\hline Raw wastewater & 14.63 & 0 \\
Almond shell & 13.13 & 10.25 \\
Eggshell & 14.43 & 1.37 \\
Pumpkin seeds & 14.00 & 4.31 \\
Banana peel & 12.57 & 14.08 \\
Rooibos tea waste & 14.00 & 4.31 \\
Green tea waste & 13.60 & 7.04 \\
Black tea waste & 13.30 & 9.10 \\
\hline
\end{tabular}

with adsorbing materials and the anthocyanin acts as a $\mathrm{pH}$ indicator in wastewater such as methyl-orange, phenolphthalein. It can be said that hydroxyl groups and methoxyl groups have a significant effect on the colour of anthocyanins. 


\section{Conclusion}

In the study, adsorption experiments were performed with different adsorbents for the removal of the anthocyanin compounds that gave colour to the turnip water wastewater. Especially the anthocyanins are very unstable and very sensitive to deterioration. Stability and colour status of anthocyanins; the presence of oxygen, light density, $\mathrm{pH}$, hydrogen peroxide, ascorbic acid, enzyme (polyphenol oxidase and peroxidase), chemical structure, co-pigment presence, metal ion, sugars and decomposition products are affected by various physical and chemical factors.

Due to these factors and the complex structure of anthocyanin the colour removal efficiencies obtained as a result of experiments using natural adsorbents vary between $1 \%$ and $14 \%$. In the study, the highest colour removal efficiencies were obtained in banana peel, almond peel and black tea waste $14.08 \%, 10.25 \%, 9.10 \%$, respectively.

\section{Compliance with ethical standards}

Conflict of interest On behalf of all authors, the corresponding author states that there is no confict of interest.

\section{References}

1. Erten H, Tangüler H (2015) Shalgam (Şalgam): a traditional Turkish lactic acid fermented beverage based on black carrot. In: Hui YH, Evranuz EÖ (eds) Handbook of vegetable preservation and processing, 2nd edn. CRC Press, Cambridge, pp 841-849

2. Toktas B, Bildik F, Ozcelik B (2018) Effect of fermentation on anthocyanin stability and in vitro bioaccessibility during shalgam (salgam) beverage production. J Sci Food Agric 98(8):3066-3075

3. Tanguler H, Erten H (2012) Occurrence and growth of lactic acid bacteria species during the fermentation of shalgam (salgam), a traditional Turkish fermented beverage. LWT-Food Sci Technol 46:36-41

4. Üçok EF, Tosun $H$ (2012) Production of shalgam juice and its' functional properties. CBU J Sci 8(1):17-26

5. Özer N, Çoksöyler FN (2015) Some chemical and microbiological properties of şalgam juice. J Food 40(1):31-38

6. Ekinci FY, Baser GM, Özcan E, Üstündağ ÖG, Korachi M, Sofu A, Blumberg JB, Chen CYO (2016) Characterization of chemical, biological, and antiproliferative properties of fermented black carrot juice, shalgam. Eur Food Res Technol 242(8):1355-1368

7. Karaoglan HA, Keklik NM, Develi Işikli N (2017) Modeling inactivation of candida inconspicua isolated from turnip juice using pulsed UV light. J Food Process Eng 40(2):1-9

8. Jakubowski M (2017) Potential and differences of selected fermented non-alcoholic beverages. World Sci News 72:204-210

9. Arslan D, Ünver A, Özcan MM (2015) A traditional fermented product: Şalgam juice, production and usage. J Agroaliment Proc Technol 21(4):309-314
10. Tangüler H, Saris PEJ, Erten H (2015) Microbial, chemical and sensory properties of shalgams made using different production methods. J Sci Food Agric 95:1008-1015

11. Tanguler H, Selli S, Sen K, Cabaroglu T, Erten H (2017) Aroma composition of shalgam: a traditional Turkish lactic acid fermented beverage. J Food Sci Technol 54(7):2011-2019

12. Tanrıseven D, Dıblan S, Selli S, Kelebek H (2018) Şalgam suyunun üretim yöntemleri ve biyoaktif bileşenleri. Artıbilim: Adana Bilim ve Teknoloji Üniversitesi Fen Bilimleri Dergisi 1(1):38-45

13. Erten $\mathrm{H}$, Tanguler $\mathrm{H}$, Canbaş A (2008) A traditional Turkish lactic acid fermented beverage: Shalgam (Salgam). Food Rev Int 24(3):352-359

14. Altay F, Karbancıoglu-Güler F, Daskaya-Dikmen C, Heperkan D (2013) A review on traditional Turkish fermented non-alcoholic beverages: microbiota, fermentation process and quality characteristics. Int J Food Microbiol 167:44-56

15. Tanguler $\mathrm{H}$, Erten $\mathrm{H}$ (2013) Selection of potential autochthonous starter cultures from shalgam, a traditional Turkish lactic-acid fermented beverage. Turk J Agric For 37:212-220

16. Türkyılmaz M, Yemiş O, Özkan M (2012) Clarification and pasteurisation effects on monomeric anthocyanins and percent polymeric colour of black carrot (Daucus carota L.) juice. Food Chem 134:1052-1058

17. Kirca A, Ozkan M, Cemeroglu B (2006) Stability of black carrot anthocyanins in various fruit juices and nectars. Food Chem 97:598-605

18. Kamiloglu S (2016) Bioavailability and bioactivity of black carrot polyphenols using in vitro digestion models combined with a co-culture model of intestinal and endothelial cell lines. Ph.D. dissertation, Faculty of Bioscience Engineering, Ghent University, Belgium

19. Giampieri F, Alvarez-Suarez JM, Battino M (2014) Strawberry and human health: effects beyond antioxidant activity. J Agric Food Chem 62:3867-3876

20. Carvalho D, Dominguez A, Neto DO, Tarjuelo J, Martinez-Romero A (2014) Combination of sowing date with deficit irrigation for improving the profitability of carrot in a tropical environment (Brazil). Sci Hortic 179:112-121

21. Algarra M, Fernandes A, Mateus N, de Freitas V, da Silva JCE, Casado J (2014) Anthocyanin profile and antioxidant capacity of black carrots (Daucus carota L. ssp. sativus var. atrorubens Alef.) from Cuevas Bajas, Spain. J Food Compos Anal 33:71-76

22. Khandare V, Walia S, Singh M, Kaur C (2011) Black carrot (Daucus carota ssp. sativus) juice: processing effects on antioxidant composition and color. Food Bioprod Process 89:482-486

23. İncedayi B, Uylaşer V, Çopur ÖU (2008) A traditional Turkish beverage shalgam: manufacturing technique and nutritional value. J Food Agric Environ 6(3-4):31-34

24. Wallace TC (2011) Anthocyanins in cardiovascular disease. Adv Nutr Int Rev J 2:1-7

25. Park S, Kang S, Jeong DY, Jeong S-Y, Park JJ, Yun HS (2015) Cyanidin and malvidin in aqueous extracts of black carrots fermented with Aspergillus oryzae prevent the impairment of energy, lipid and glucose metabolism in estrogen-deficient rats by AMPK activation. Genes Nutr 10:1-14

26. Ali I, Al-Othman ZA, Alwarthan A (2017) Molecular uptake of congo red dye from water on iron composite nano particles. J Mol Liq 224:171-176

27. Lingamdinne LP, Singh J, Choi JS, Chang YY, Yang JK, Karri RR, Koduru R (2018) Multivariate modeling via artificial neural network applied to enhance methylene blue sorption using graphene-like carbon material prepared from edible sugar. J Mol Liq 265:416-427

28. Karri RR, Marjan T, Yaraki MT, Sahu JN (2018) Optimization and modeling of methyl orange adsorption onto polyaniline nano-adsorbent through response surface methodology and 
differential evolution embedded neural network. J Environ Manag 223:517-529

29. Alharbi OML, Basheer AA, Khattab RA, Ali I (2018) Health and environmental effects of persistent organic pollutants. J Mol Liq 263:442-453

30. Basheer AA (2018) Chemical chiral pollution: impact on the society and science and need of the regulations in the 21 st century. Chirality 30:402-406

31. Shafiq M, Alazba AA, Amin MT (2018) Removal of heavy metals from wastewater using date palm as a biosorbent: a comparative review. Sains Malays 47:35-49

32. Tafti AG, Rashidi A, Tayebi HA, Yazdanshenas ME (2018) Comparison of different kinetic models for adsorption of acid blue 62 as an environmental pollutant from aqueous solution onto mesoporous Silicate SBA-15 modified by tannic acid. Int J Nano Dimens 9:79-88

33. APHA-AWWA-WEF (2005) Standard methods for the examination of water and wastewater, 21 st edn. American Public Health Association/American Water Works Association/Water Environment Federation, Washington

34. Anonymous (2003) TS 11149 Standard of Turnip Juice. Turkish Standards Institute, Ankara (In Turkish)

35. Çankaya A, Tangüler H (2018) Effect of temperature on microbial change during carrot fermentation in Shalgam beverage production. Turk J Agric-Food Sci Technol 6(6):749-755

36. Coskun F (2017) A traditional Turkish fermented non-alcoholic beverage, "Shalgam". Beverages 3:1-13

37. Sevimli-Gur C, Cetin B, Akay S, Gulce-Iz S, Yesil-Celiktas O (2013) Extracts from black carrot tissue culture as potent anticancer agents. Plant Foods Hum Nutr 68:293-298

38. Okcu G, Ayhan K, Altuntas EG, Vural N, Poyrazoglu ES (2016) Determination of phenolic acid decarboxylase produced by lactic acid bacteria isolated from shalgam (salgam) juice using green analytical chemistry method. LWT-Food Sci 66:615-621

39. Quina MJ, Soares MAR, Quinta-Ferreira R (2017) Applications of industrial eggshell as a valuable anthropogenic resource. Resour Conserv Recycl 123:176-186

40. Roongruangsri W, Bronlund JE (2016) Effect of air-drying temperature on physico-chemical, powder properties and sorption characteristics of pumpkin powders. Int Food Res J 23:962-972

41. İzgi MS, Saka C, Baytar O, Saraçoğlu G, Şahin Ö (2019) Preparation and characterization of activated carbon from microwave and conventional heated almond shells using phosphoric acid activation. Anal Lett 52:772-789

42. Pathak PD, Mandavgane SA, Kulkarni BD (2017) Fruit peel waste: characterization and its potential uses. Curr Sci 113:444-454

43. Demiral İ, Şamdan CA (2016) Preparation and characterisation of activated carbon from pumpkin seed shell using $\mathrm{H}_{3} \mathrm{PO}_{4}$. Anadolu Univ J Sci Technol A Appl Sci Eng 17:125-138

44. Liu L, Fan S, Li Y (2018) Removal behavior of methylene blue from aqueous solution by tea waste: kinetics, isotherms and mechanism. Int J Environ Res Public Health 15:1-16

45. Benitez A, Gonzalez-Tejero M, Caballero A, Morales J (2018) Almond shell as a microporous carbon source for sustainable cathodes in lithium-sulfur batteries. Materials 11:1-15
46. Al-awwal NY, Ali UL (2015) Proximate analyses of different samples of egg shells obtained from Sokoto market in Nigeria. Int J Sci Res 4:564-566

47. Sulyman M, Namiesnik J, Gierak A (2017) Low-cost adsorbents derived from agricultural by-products/wastes for enhancing contaminant uptakes from wastewater: a review. Pol J Environ Stud 26:479-510

48. Gopiraman M, Saravanamoorthy S, Kim SH, Chung III-M (2017) Interconnected meso/microporous carbon derived from pumpkin seeds as an efficient electrode material for supercapacitors. Carbon Lett 24:73-81

49. Mujaffar S, Ramsumair S (2019) Fluidized bed drying of pumpkin (Cucurbita sp.) seeds. Foods 8:1-13

50. Abubakar US, Yusuf KM, Safiyanu I, Abdullahi S, Saidu SR, Abdu GT, Indee AM (2016) Proximate and mineral composition of corn cob, banana and plantain peels. Int J Food Sci Nutr 1:25-27

51. Ghasemi S, Gholani RM, Yazdanian M (2017) Biosorption of heavy metal from cadmium rich aqueous solutions by tea waste as a low cost bio-adsorbent. Jundishapur J Health Sci 9:1-8

52. Grootaert C, Kamiloglu S, Capanoglu E, Van Camp J (2015) Cell Systems to investigate the impact of polyphenols on cardiovascular health. Nutrients 7(11):9229-9255

53. Guldiken B, Boyacioglu D, Capanoglu E (2016) Optimization of extraction of bioactive compounds from black carrot using response surface methodology (RSM). Food Anal Methods 9:1876-1886

54. Arscott SA, Tanumihardjo SA (2010) Carrots of many colors provide basic nutrition and bioavailable phytochemicals acting as a functional food. Compr Rev Food Sci Food Saf 9:223-239

55. Kamiloglu S, Capanoglu E, Grootaert C, Van Camp J (2015) Anthocyanin absorption and metabolism by human intestinal Caco-2 cells-a review. Int J Mol Sci 16(9):21555-21574

56. Keleş Y (2015) Antosiyanin pigmentlerin biyokimyası ve analizi. Türk Bilimsel Derlemeler Dergisi 8(1):19-25

57. Koley TK, Singh S, Khemariya P, Sarkar A, Kaur C, Chaurasia SNS, Naik PS (2014) Evaluation of bioactive properties of Indian carrot (Daucus carota L.): a chemometric approach. Food Res Int 60:76-85

58. Kong J-M, Chia L-S, Goh N-K, Chia T-F, Brouillard R (2003) Analysis and biological activities of anthocyanins. Phytochem 64:923-933

59. Ignat I, Volf I, Popa VI (2011) A critical review of methods for characterisation of polyphenolic compounds in fruits and vegetables. Food Chem 126:1821-1835

60. Tsuda T (2012) Dietary anthocyanin-rich plants: biochemical basis and recent progress in health benefits studies. Mol Nutr Food Res 56:159-170

Publisher's Note Springer Nature remains neutral with regard to jurisdictional claims in published maps and institutional affiliations. 